\title{
Demographic drivers of Norway rat populations from urban slums in Brazil
}

\author{
C. G. Zeppelini ${ }^{1,2}$ (D) - T. Carvalho-Pereira ${ }^{3} \cdot$ R. Sady Alves ${ }^{4}$ - D. C. C. Santiago ${ }^{5}$ V. F. Espirito Santo ${ }^{6} \cdot$ M. Begon $^{7} \cdot$ \\ F. Costa ${ }^{3} \cdot$ Hussein Khalil ${ }^{8}$
}

Accepted: 19 November 2020 / Published online: 18 December 2020

(C) The Author(s) 2020

\begin{abstract}
The Norway rat is a globally distributed pest, known for its resilience to eradication and control programs. Efficient population control, especially in urban settings, is dependent on knowledge of rat demography and population ecology. We analyzed the relationship between four demographic outcomes, estimated by live-trapping data, and fine-scale environmental features measured at the capture site. Wounds, a proxy for agonistic interactions, were associated with mature individuals. Areas with environmental features favorable to rats, such as open sewers and unpaved earth, were associated with more mature individuals with a better body condition index. The control measures (environmental stressors) are likely to be disrupting the social structure of rat colonies, increasing the frequency and distribution of agonistic interactions, which were common in both sexes and maturity states. The relationship between the favorable environmental conditions and the demographic markers analyzed indicate possible targets for infestation control through environmental manipulation, and could be incorporated into current pest management programs to achieve long-term success. Our study indicate that urban interventions focused on removal of potential resources for rats could be potential long-term solutions by reducing the carrying capacity of the environment.
\end{abstract}

Keywords Rattus norvegicus $\cdot$ Urban ecology $\cdot$ Demography $\cdot$ Tropics $\cdot$ Slums $\cdot$ Zoonotic disease $\cdot$ Salvador

\section{Introduction}

The Norway rat (Rattus norvegicus) is one of the most successful worldwide colonizers in evolutionary history (Morand et al. 2015). The genus Rattus has historically tracked human movement, dispersing from its origins in Asia to Europe, and then to the rest of the world by the advent of long-distance routes such as the Silk Route and the trans-Atlantic navigations (Puckett et al. 2016). Today, the Norway rat is present in all populated continents and its occurrence is closely

C. G. Zeppelini

czeppelini@gmail.com

Hussein Khalil

hussein.khali1@slu.se

1 Laboratório de Mamíferos, Universidade Federal da Paraíba, Cidade Universitária, João Pessoa, Brazil

2 Programa de Pós-Graduação em Ecologia: Teoria, Aplicações e Valores, Universidade Federal da Bahia, R. Barão do Geremoabo, Salvador 147, Brazil

3 Instituto de Saúde Coletiva, Universidade Federal da Bahia, R. Basílio da Gama, S/N, Salvador, Brazil associated with humans (Himsworth et al. 2014), being able to colonize a diversity of man-made habitats (urban areas, parklands, farmlands) (Glass et al. 1989).

Its adaptability to a variety of human-created habitats, particularly urban areas (McKinney 2002), and their biological traits, make the Norway rat a ubiquitous pest. In agricultural areas they damage crops and contaminate stored harvests, and in urban environments they cause structural damage (e.g. gnawing on electric wires, damaging house structures by burrowing) and are reservoirs to several zoonotic pathogens

4 Programa de Pós-Graduação em Ciência Animal nos Trópicos, Universidade federal da Bahia, R. Barão do Geremoabo, Salvador 147, Brazil

5 Instituto de Biologia, Universidade Federal da Bahia, R. Barão do Geremoabo, Salvador 147, Brazil

6 Faculdade de Farmácia, Universidade Federal da Bahia, R. Barão do Geremoabo, Salvador 147, Brazil

7 Institute of Integrative Biology, University of Liverpool, Biosciences Building, Liverpool L69 7ZB, UK

8 Department of Wildlife, Fish and Environmental Studies, Swedish University of Agricultural Sciences, SE-901 83 Umeå, Sweden 
(Desvars-Larrive et al. 2017). The estimated damage caused by rats reaches hundreds of billions of dollars annually, greater than the calculated damage caused by, for example, air pollution mortality (Parsons et al. 2017).

In urban settings, rat infestation is usually associated with poor communities (slums, sensu Costa et al. (2014a)), where precarious infrastructure and deficient urban services such as trash collection and adequate sanitation create favorable conditions for high rat population density (Minter et al. 2018). In slums, rats carry and transmit both bacterial and viral pathogens (Costa et al. 2014a). Amongst the diversity of pathogens associated with rat infestations, leptospirosis is the greatest public health threat, with especially high incidence in urban areas and slums, where the environment facilitates disease transmission (Costa et al. 2014a; Garchitorena et al. 2017; Himsworth et al. 2013).

Aside from a few successes on islands (Innes 2001; Robertson and Gemmell, 2004), rats have resisted most eradication efforts. Control has relied heavily on rodenticide application (Costa et al. 2014b), but populations usually recover within a few months (Masi et al. 2009). This method also involves risks to non-target species (Santos et al. 2017), and resistance to rodenticides can develop over time (Lutermann et al. 2017). It is thus necessary to transition to a strategy focused on managing the landscape and the resources exploited by rats (Colvin et al. 1996). However, the design of effective control measures depends on a solid understanding of the ecology of the target species in general and especially at the site to be managed. This is necessary to inform decisions regarding management options, such as defining eradication units (i.e., the spatial unit for management), timing of implementation, and selecting adequate interventions (Parsons et al. 2017; Robertson and Gemmell, 2004).

Despite the proximity between humans and rats, our knowledge of rat ecology in urban settings is still incipient (Combs et al. 2018). Most studies have been conducted in developed areas with temperate climate, with an emphasis on rats' use of space and movement (Byers et al. 2017; Davis and Fales, 1950; Davis and Hall 1951; Himsworth et al. 2015; Himsworth et al. 2014), which have limited relevance to the less organized reality of developing countries in the tropics (Desvars-Larrive et al. 2018). Moreover, little is known about how the environment influences rats' demography on a local scale.

One of the main challenges faced today in pest control is understanding the demography and ecology of the species of interest (Cavia et al., 2009; Dexter 2003; Edwards et al. 2004; Hampton et al. 2004; Zenger et al. 2003), which may define the spatial and temporal parameters of an intervention taking in account reproduction, variations in spatial occupation and temporal phenomena. Furthermore, in scenarios where the target species involved is a zoonotic reservoir, population structure is relevant for current and future migration (as the use of space, home range and migration differ between sexes and maturity stages), and to the rate of transmission among infected and newly recruited or immigrant individuals (Byers et al. 2019b). The present study aims to describe demographic data for urban Rattus norvegicus populations at four study sites in Salvador, Brazil, to investigate the role of environmental factors and control efforts in determining the population structure in these sites. Our hypotheses are that resources (e.g. trash, water bodies) and other favorable environmental traits (e.g. burrowable soil) will foster a more stable rat population with better body condition, whereas the deployment of rodent control efforts will have negative effects on the populations (lower body condition, survival and more aggression).

\section{Materials and methods}

\section{Study areas}

Four urban slum communities (sensu Costa et al. (2014a)) were sampled in the city of Salvador, Bahia in Brazil, namely Marechal Rondon (MR), Alto do Cabrito (AC), Rio Sena (RS) and Nova Constituinte (NC) (Fig. 1). We live-trapped rats during two campaigns in each community. The first campaign was between April and June 2018, and the second between October and November 2018, representing rainy and dry seasons, respectively. The sampling areas were between 0.07 and $0.09 \mathrm{~km}^{2}$ with an altitudinal gradient (slopes and valley bottoms) characteristic of urban slums in the city of Salvador. The areas were selected by the similarity of their conditions (socioeconomic, geographic relief, house and urban infrastructure) and their location within the same sanitary district in the Zoonosis Control Center classification, characterized by high numbers of complaints about rat infestation, as well as leptospirosis cases records.

\section{Sampling and data collection}

Sampling locations were selected using conditioned random sampling. Every residence in the study area received a number and a geotag within the area, and forty evenly spaced random points were selected for sampling, in order to adequately represent the community. Two Tomahawk live traps baited with sausage were deployed in each point for four nights, totaling 320 attempted trap-nights per campaign in each area and 640 trap-nights per community. The traps were located in peridomestic settings such as back yards after obtaining permission from the residents.

For each sampling point, an environmental survey questionnaire was applied by field personnel through visual inspection of the peri-domestic environment and interviewing the head of the household. We gathered data on environmental and socioeconomic variables, such as the presence of trash 

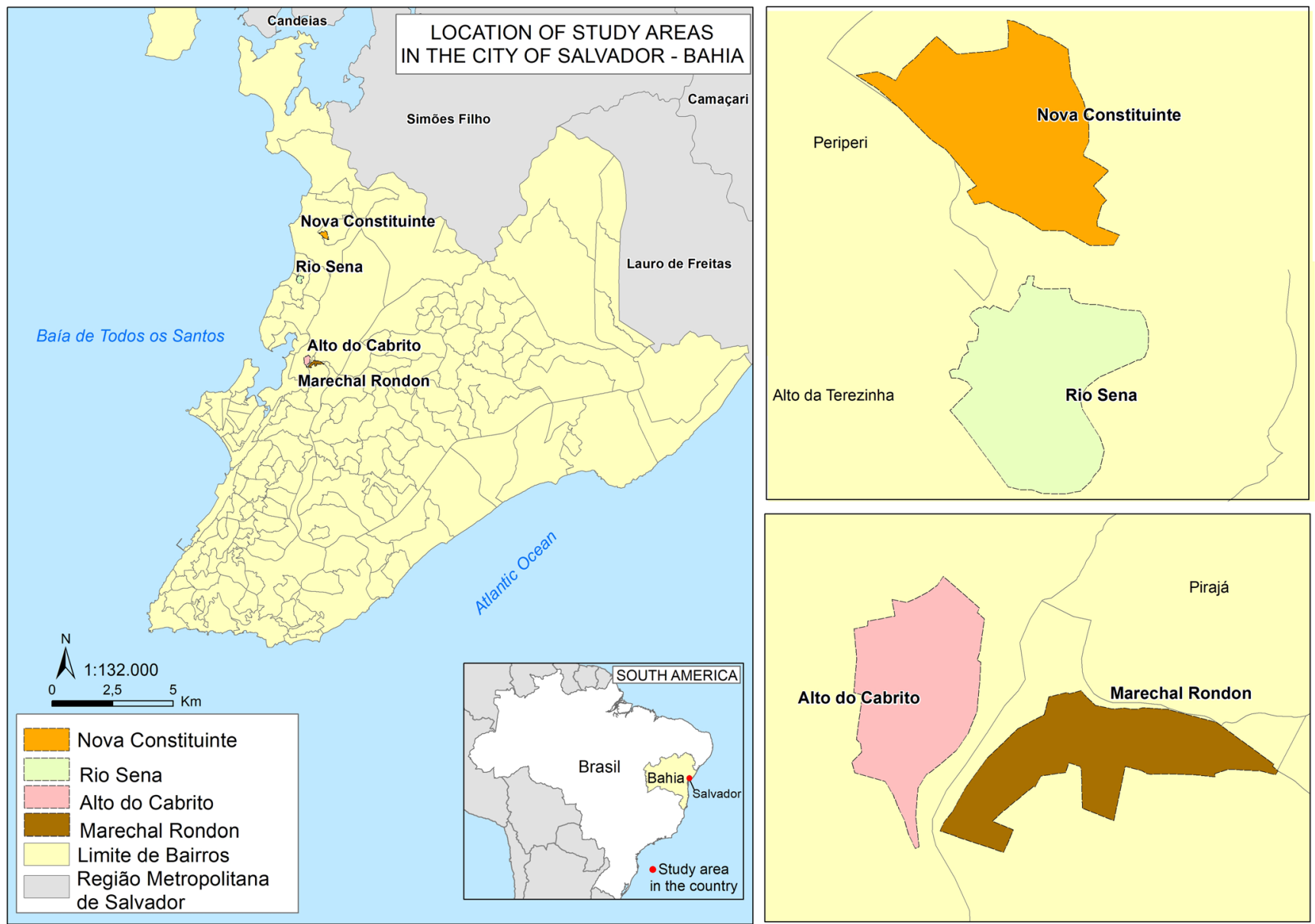

Fig. 1 Map of the four communities studied in the city of Salvador, Bahia, Brazil. MR = Marechal Rondon; AC = Alto do Cabrito; RS = Rio Sena; NC= Nova Constituinte. Map produced by Dr. Ricardo Lustosa Brito

Table 1 Variables collected for the models based in the Integrated Pest Management outdoor inspection form (CDC) for environmental factors associated to rodent infestation, as recorded within the 20-m buffer around each sampled household

\begin{tabular}{|c|c|}
\hline Variable & explanation and formatting \\
\hline $\begin{array}{l}\text { Type of ground } \\
\text { coverage }\end{array}$ & $\begin{array}{l}\text { Categorical (pervious, semi-pervious, impervious). Whether the soil in the buffer is } \\
\text { paved or not }\end{array}$ \\
\hline Presence of sewers & $\begin{array}{l}\text { Presence/absence. Presence of a sewer canal within the } 20 \mathrm{~m} \text { buffer of the sampling } \\
\text { point (household) }\end{array}$ \\
\hline Water bodies & $\begin{array}{l}\text { Categorical (water body, leak, puddle, absent). Presence and type of water body or } \\
\text { other water source }\end{array}$ \\
\hline Available residues & Presence/absence. Presence of construction debris and/or household trash \\
\hline Opossums & $\begin{array}{l}\text { Presence/absence. Whether there were opossums captured in the sampling } \\
\text { point/buffer }\end{array}$ \\
\hline Dogs & $\begin{array}{l}\text { Presence/absence and counts. Whether there are dogs residing within the buffer zone } \\
\text { (household reported) }\end{array}$ \\
\hline Cats & See dogs \\
\hline $\mathrm{CCZ}$ visits & $\begin{array}{l}\text { Presence/absence. Whether the Zoonosis Control Center }(\mathrm{CCZ}) \text { has visited the area in } \\
\text { the last } 12 \text { months (household reported) }\end{array}$ \\
\hline Use of rodenticides & $\begin{array}{l}\text { Presence/absence. Whether the local residents deploy some type of chemical } \\
\text { rodenticide in the area in the last } 12 \text { months (household reported) }\end{array}$ \\
\hline $\begin{array}{l}\text { Presence of Capillaria } \\
\text { hepatica }\end{array}$ & $\begin{array}{l}\text { Presence/absence. Whether the necropsied individual presented signs of } C \text {. hepatica } \\
\text { in the liver. }\end{array}$ \\
\hline
\end{tabular}


accumulation sites and visits from the Zoonosis Control Center (CCZ) agents (Table 1, Supplementary Material 1), which were potential explanatory variables for the demographic features of rats within the communities.

After capture, rats were transported to a field lab, where they were euthanized according to a standardized protocol (sedation induced by Isoflurane, followed by euthanasia by intraperitoneal sodium thiopental) (Costa et al. 2015). The animals were then taxonomically identified, body measures taken, and dissected for the collection of biological samples. During the dissection of the specimen, the head, paws and tail were inspected for wounds or scars. Wounds were analyzed only in terms of presence or absence as a proxy for agonistic interactions and stress. In examining specimens, it was not possible to determine whether the wound intensity observed is the outcome of one or few intense attritions, or several lower intensity encounters. During dissection, the presence of Capillaria hepatica infestation was observed by examining the liver for the presence of fibrosis scars visible on the surface of the organ (Stojčević et al. 2002) as a possible co-measure for health. For the body condition index, we used the Scaled Mass Index (SMI), which is based on the weight-length ratio, whilst accounting for the effect of age (Peig and Green, 2009), allowing to use body size as a proxy for health. Pregnant individuals had their weight adjusted following the method by Minter et al. (2017). Animals were classified as mature if a) they were over the $200 \mathrm{~g}$ threshold, considered as a viable surrogate for sexual maturity (Porter et al. 2015) or b) they presented physical sexual maturity signs (i.e. fully descended scrotal testes for males, perforated vagina for females). All procedures were performed under ethical approval by the Ethical Committee of the Animal Use (CEUA) protocol number 019/2016 of the IGM - Oswaldo Cruz Foundation (Fiocruz)

\section{Data analysis}

To investigate the main environmental drivers for demographic parameters, namely the sex ratio (proportion of males to females), maturity ratio (proportion of adults to juveniles), presence of wounds and SMI, we used Generalized Linear Mixed Effect Models (glm). As explanatory variables, we used the covariates informed from the questionnaires and field data (Supplementary Material 1). We used area (each of the 4 communities) as a fixed effect.

For each outcome, we defined a pool of potential explanatory variables (Table 1) based on our hypotheses (Supplementary Material 1 presents the variables and their hypothesized effect on parameter of interest). To check for collinearity among the explanatory variables, we used Pearson's chi-squared or Fisher's Exact test for categorical data, or a Spearman's Rank Sum Correlation for count data. The covariate pool for the sex model was formed by ten variables (presence of opossums, available residues, category of water body, presence of sewers in a $20-\mathrm{m}$ radius, CCZ (Zoonosis Control Center) visits, application of rodenticide poison baits by the population, presence and number of cats, presence and number of dogs). There were 11 covariates for the maturity model (sex, presence of opossums, available residues, category of water body, presence of sewers in a $20-\mathrm{m}$ radius, $\mathrm{CCZ}$ visits, application of rodenticide poison baits, presence and number of cats, presence and number of dogs, type of ground coverage); 15 for wounds (sex, presence of opossums, available residues, category of water body, presence of sewers in a 20-m radius, CCZ visits, application of rodenticide poison baits, presence and number of cats, presence and number of dogs, type of ground coverage, maturity, SMI, accumulated materials). For SMI, there were 14 covariates (sex, presence of opossums, available residues, category of water body, presence of sewers in a $20-\mathrm{m}$ radius, CCZ visits, application of rodenticide poison baits, presence and number of cats, presence and number of dogs, type of ground coverage, maturity, accumulated materials).

Before fitting the full model, for presence of wounds, we ran a primary model including sex, maturity and the interaction between the two. With the defined covariate pool for each outcome, we created a multivariable global model, and ran a model selection using Akaike's Information Criterion (AIC). The models discussed are the ones considered plausible ( $\triangle \mathrm{AIC}<2$ compared to the model with the lowest AIC) (Burnham and Anderson 2002). We chose as the most parsimonious model, the one with a $\triangle \mathrm{AIC}<2$ and the fewest number of explanatory variables. To determine the strength of support for the explanatory variables considered in the set of models, the sum of 'Akaike weights' over all models including the explanatory variable (or simply, 'relative variable importance') was used. All analyses were performed in R v3.5.1 using the packages 'Tidyverse', 'lme4' and 'MuMIn' (Barton 2018; Bates et al. 2015; R Core Team 2018; Wickham 2017).

\section{Results}

\section{Descriptive statistical summary}

In the two campaigns, we captured a total of 118 individuals of Rattus norvegicus (trap success of 0.2063 captures per trapnight), of which three were removed from the analysis due to absence of sex or maturity data (Table 2). We lost fourteen trap-nights in Alto do Cabrito due to flooding, as well as 17 in Marechal Rondon, 15 in Rio Sena and 22 in Nova Constituinte. The majority of captures were adults $(N=85)$, with a sex ratio slightly skewed towards females at 1:1.21. For both sexes, adults had more wounds. Notably, all adult 
Table 2 Demographic summary of the captured Rattus norvegicus in four communities, means with S.D. giver in parenthesis. Females have two values for weight due to the presence of pregnant females. Values in bold font have been corrected to account to pregnant individuals

\begin{tabular}{|c|c|c|c|c|c|c|c|}
\hline & & \multirow[t]{2}{*}{ Body Mass (g) } & \multirow[t]{2}{*}{ Body Lenght (mm) } & \multirow[t]{2}{*}{ SMI } & \multicolumn{2}{|l|}{ Wounds } & \multirow{2}{*}{$\begin{array}{l}\text { Presence of } \\
\text { Capillaria } \\
\text { hepatica scars } \\
\text { in liver }\end{array}$} \\
\hline & & & & & present & absent & \\
\hline \multirow[t]{2}{*}{ Male } & adult $(N=46)$ & $274.83 \pm 86.53[105-460]$ & $211.65 \pm 19.51[163-250]$ & $275.42 \pm 38.6[195.23-370.46]$ & 41 & 5 & 30 \\
\hline & sub-adult $(N=6)$ & $90.42 \pm 59.9[30-195]$ & $142.17 \pm 26.51[105-179]$ & $279.22 \pm 52.7[183.67-338.12]$ & 3 & 3 & 1 \\
\hline \multirow[t]{2}{*}{ Female } & adult $(N=39)$ & $\begin{array}{l}302.63 \pm 63.06 \\
\quad(\mathbf{2 6 1 . 4} \pm \mathbf{9 3 . 2 8}) \\
{[145-400][\mathbf{3 0}-\mathbf{4 6 0}]}\end{array}$ & $221.46 \pm 18.48[173-273]$ & $276.49 \pm 41.87[164.69-380.58]$ & 39 & 0 & 32 \\
\hline & sub-adult $(N=24)$ & $213 \pm 79.46[85-350]$ & $198.67 \pm 27.42[150-237]$ & $257.62 \pm 42.35$ [196.86-349.99] & 20 & 4 & 15 \\
\hline \multirow[t]{2}{*}{ Total } & adult $(\mathrm{N}=85)$ & $291.44 \pm 82.33[105-460]$ & $216.15 \pm 19.56[163-273]$ & $271.78 \pm 40.09[164.69-380.58]$ & 80 & 5 & 62 \\
\hline & sub-adult $(N=30)$ & $188.48 \pm 90.07[30-350]$ & $187.37 \pm 35.29[105-237]$ & $261.94 \pm 44.48[183.67-349.99]$ & 23 & 7 & 16 \\
\hline
\end{tabular}

females showed wounds or scars. Wounds were frequent in adults (80/85) and juveniles (23/30).

\section{Outcome models}

\section{Sex}

The model selection recovered the null model (sex ratio $\sim 1$ ) as the most parsimonious of the 17 models with $\Delta \mathrm{AIC}<2$.

\section{Maturity}

For the 18 plausible models $(\triangle \mathrm{AIC}<2)$ in the classification, two variables (presence of sewers and sex) were present in all models; while type of water body was present in all but two of the plausible models (Supplementary Material 2). The most parsimonious model included presence of sewers and sex, $(\triangle \mathrm{AIC}=0.84)$. The model considered being male $(\mathrm{OR}$ 5.597, $p=0.001$ ) and the presence of sewers (OR 3.336, $p=$ 0.01 ) as positively associated with the likelihood of capturing adults (Table 3 ).

The relative variable importance assigned the strongest support for sex (weight $=0.99$ ) and presence of sewers (0.95) all present in 4096 models.

\section{Wounds}

The variables "presence of cats" and "number of cats" were responsible for causing a "perfect separation" error during the model run, and so "number of cats" was dropped from the model.

There were 24 models within the $\triangle \mathrm{AIC}$ threshold. Two parsimonious models were selected, one comprising presence of dogs, maturity, sex and rodenticides, while the second substituted presence of dogs for CCZ activity (Supplementary Material 2). Both models detected a large negative effect of the presence of rodenticide (model 1: OR
$0.122, p=0.008$; model 2 OR 0.206, $p=0.03$ ), and being male (model 1 OR $0.075, p=0.01$; model 2 OR $0.06, p=$ 0.009 ), as well as a strong positive effect of being a sexually mature individual (model 1 OR 23.793, $\mathrm{p}=0.001$; model 2 OR 20.516, $p=0.002$ ) in the chance of capturing wounded animals. The second parsimonious model, however, also detected the effect $\mathrm{CCZ}$ activity in the area (OR 7.715, $p=$ 0.034) (Table 3).

The relative variable importance assigned the strongest support for maturity (weight $=0.99)$, sex $(0.96)$, the use of rodenticide poison (0.9), number of dogs (0.71), and $\mathrm{CCZ}$ activity (0.58), all present in 8192 models.

\section{SMI}

The model selection recovered 15 models within the $\triangle \mathrm{AIC}$ threshold. The most parsimonious model included CCZ activity, accumulated materials, presence of sewers and type of soil coverage (Supplementary Material 2), which were present in all 15 models, and were all considered as having a significant effect on SMI. CCZ activity $(\beta-24.0, p=0.002)$ and accumulated materials $(\beta-23.7, p=0.04)$ had a negative effect, while presence of sewers $(\beta 18.4, p=0.01)$ and type of ground coverage $(\beta 23.2, p=0.006)$ had a positive association (Table 3).

The relative variable importance assigned the strongest support for $\mathrm{CCZ}$ activity (weight $=0.87$ ), accumulated materials $(0.77)$, presence of sewers $(0.75)$, type of ground coverage $(0.72)$, sex (0.54) and number of dogs $(0.54)$, all present in 16,384 models.

\section{Discussion}

Here, we observed that environmental features related to resources or shelter, such as open sewers, could affect the characteristics of urban Norway rat populations. On the other 
Table 3 Size and effect of the variables that compose the selected models, with lower (2.5\%) and upper (97.5\%) confidence intervals and statistical significance

\begin{tabular}{|c|c|c|c|c|c|}
\hline & OR & $2.5 \%$ & $97.5 \%$ & Std. Error & $P$ value \\
\hline \multicolumn{6}{|l|}{ Maturity } \\
\hline (Intercept) & 0.766 & 0.351 & 1.625 & 0.3868 & 0.489 \\
\hline Presence of sewers & 3.336 & 1.344 & 8.667 & 0.4722 & 0.010 \\
\hline Sex (male) & 5.597 & 2.104 & 17.159 & 0.5286 & 0.001 \\
\hline \multicolumn{6}{|l|}{ Wounds: model 1} \\
\hline (Intercept) & 8.787 & 2.523 & 57.655 & 0.7138 & 0.002 \\
\hline Presence of dogs & 1.759 & 1.084 & 3.905 & 0.3023 & 0.061 \\
\hline Maturity (adult) & 23.793 & 3.938 & 213.606 & 0.9955 & 0.001 \\
\hline Sex (male) & 0.075 & 0.008 & 0.444 & 1.0056 & 0.01 \\
\hline Presence of rodenticide & 0.122 & 0.022 & 0.544 & 0.8013 & 0.008 \\
\hline \multicolumn{6}{|l|}{ Wounds: model 2} \\
\hline (Intercept) & 7.485 & 2.115 & 37.016 & 0.7148 & 0.004 \\
\hline CCZ activity & 7.623 & 1.447 & 72.908 & 0.9603 & 0.003 \\
\hline Maturity (adult) & 20.516 & 3.442 & 197.763 & 1.0033 & 0.002 \\
\hline Sex (male) & 0.064 & 0.006 & 0.405 & 1.0632 & 0.009 \\
\hline \multirow[t]{2}{*}{ Presence of rodenticide } & 0.206 & 0.044 & 0.839 & 0.7350 & 0.031 \\
\hline & $\beta$ & $2.5 \%$ & $97.5 \%$ & Std. Error & $P$ value \\
\hline \multicolumn{6}{|l|}{ SMI } \\
\hline (Intercept) & 272.99 & 249.033 & 296.947 & 12.223 & $<2 \mathrm{e}-16$ \\
\hline CCZ activity & -24.007 & -39.195 & -8.818 & 7.749 & 0.002 \\
\hline Accumulated materials & -23.725 & -46.192 & -1.258 & 11.463 & 0.040 \\
\hline Presence of sewers & 18.426 & 3.297 & 33.554 & 7.719 & 0.018 \\
\hline Unpaved soil & 23.208 & 6.833 & 39.583 & 8.355 & 0.006 \\
\hline
\end{tabular}

hand, environmental stressors ( $\mathrm{CCZ}$ visits and rodenticides, which remove individuals from the population and could be considered an environmental pressure) decreased SMI.

Wounds and scars, used as a proxy for agonistic interactions (Feng and Himsworth, 2014), were present mostly in adults (Glass et al. 1989; Himsworth et al. 2014). However, the association between wounds and being female in our model - wounds were 9\% more frequent in females, and all adult females were wounded - contradicted previous association between wound prevalence and being male (Himsworth et al. 2014), as well as another study that found no association between sex and wounding (Costa et al. 2014a). Agonistic encounters may be driven by sex-specific factors that could lead to fights over social hierarchy and territory. Male and female adults display aggressive behaviors towards intruders, although female aggression tends less frequently to wound the invader, whereas males often retaliate and wound (Blanchard et al. 1984). Female aggression could also be linked to parental defense, as postpartum and lactating females in particular display aggressive behaviors towards intruders and other potential threats (Gioverdani et al. 2000).

In either scenario, the frequency of aggression could be exacerbated by environmental disturbances (in this case, the control efforts), which may cause the concentration of individuals into favorable (and/or disturbance-free) areas where colonies and/or parous female nests are located, increasing the density there and thus the chances of agonistic encounters. Whether the presence of the control measures does lead to the spatial concentration of individuals needs to be tested. There is currently a paucity of studies on wild rat behavior (Clapperton 2006; Macdonald et al. 1999), hindering any association between the effect detected and potential behavioral causes. The effect of maturity on wounding is expected due to the longer lifespan offering more opportunities to incur in aggressive encounters, as well as the role of sexually mature individuals in territorial defense.

Rodent control methods, which were expected to act as a disturbance and thus expected to cause more wounding, greatly diminished the capture of wounded rodents. Our assumption was based on experimental studies which found that manipulation of socio-environmental factors in rat colonies can cause changes in aggressiveness, especially when territory is manipulated (Meaney and Stewart, 1979). The negative association found in our study could indicate that there is a trappability bias in areas where constant rodenticide application and $\mathrm{CCZ}$ visits occur, removing the older, more experienced individuals (and likely more wounded), increasing the odds of more naïve adults being captured. This could be one 
of the environmental features that regulate rat trappability in urban settings (Byers et al. 2019a).

SMI was affected by a range of factors, including sex and maturity, both of which relationships have been detected previously (Panti-May et al. 2016). The application of rodenticides by the CCZ negatively influenced the SMI, while resources such as sewers and exposed earth increased the SMI in accordance with our hypotheses. 'Accumulated materials', however, showed a negative association with the SMI. This may indicate that there is a need for a finer separation of the variables to understand the ecological drivers of body condition, as this variable includes both construction debris and inorganic household refuse (such as broken home appliances, boxes, etc.), which could have different utility as hiding places, pose threats to animal occupation (i.e. presence of broken glass, sharp objects) and interact differently with the surrounding environment. It is also likely that accumulated materials diminish environmental quality, which reflects in the body condition of the occupant individuals.

The majority of individuals in the four study areas were adults, which is different from what was reported in other areas in Brazil (Panti-May et al. 2016), but has been detected in other studies in the Americas and Europe in an urban context (e.g. Desvars-Larrive et al. (2017); Himsworth et al. (2014); Villafañe et al. (2013)). Two out of four variables selected by the models (sewers, water bodies) are resources, which could explain the higher occurrence of adults, as resource availability is one of the main factors dictating home range selection on rats, with resource-abundant areas being normally held by adult individuals (Byers et al. 2019b; Macdonald et al. 1999), especially as water puddles are more likely to be used as drinking sources, in contrast to our earlier hypothesis. The effect of sex is likely present due to $88.4 \%$ of the males being adult.

With a sex ratio close to one to one ( $54.7 \%$ females), the populations studied differ from what has been registered in higher latitudes (Desvars-Larrive et al. 2017; Glass et al. 1989; Himsworth et al. 2014), while other studies performed in Brazil have recorded similar sex ratios (Panti-May et al. 2016; Porter et al. 2015), possibly indicating a pattern for populations in tropical urban areas. A population dominated numerically by females, however, seems to be the exception (e.g. Villafañe et al. (2013)). The higher number of females could also indicate a population response to the abundance of food and mild climate throughout the year, as populations in the tropics display continuous reproduction due to a yearround warm weather (Panti-May et al. 2016), but this can only be verified with a long-term study.

Our main findings give empirical support to the need for the transition into a landscape management practice (Colvin et al. 1996). Within these findings, we confirm the importance of managing sewers and water bodies, important resources and pathways for Norway rat movement, within areas with rat infestation (Gurtler et al. 2008; Masi and Pino 2011; Traweger et al. 2006), so naturally efforts in closing sewers and improving the sanitation around water bodies could have a positive effect in reducing rat infestation by reducing the available water supply for rat colonies, while also protecting the local population from contamination from zoonosis such as leptospirosis (Felzemburgh et al. 2014), which are linked both to contaminated water and rat infestation. We have also found that the presence of burrowable, unpaved ground is a key resource for the presence of rats in good health condition within an area, which points to two pathways to manage the landscape: i) pavement and maintenance of streets and paths, ii) management and maintenance of vacant lots and yards to avoid their use as burrow sites. With an organized pavement, drainage and landscaping plan, it is possible to greatly reduce the environmental carrying capacity (Lambert et al. 2017; Orgain and Schein 1953) of the areas and impede the continuous poverty-trap of urban neglect and pest infestation.

Supplementary Information The online version contains supplementary material available at https://doi.org/10.1007/s11252-020-01075-2.

Acknowledgments We would like to thank the field crew of Projeto Caza for their efforts and diligence during the trapping campaigns, the necropsy crew for their dedication, keen eye and ethics, and the Exotic and Sylvatic Animal Ambulatory (AASE) for lending us laboratory space for the necropsies. This study could not be performed without the enthusiastic assistance of the community leaders and residents of the four communities where field work took place. This study was funded by a grant awarded by the Medical Research Council (MRC) of the United Kingdom (award MR/P024084/1) and FAPESB (10206/2015). CGZ doctoral studies are supported by a scholarship granted by the Foundation for the Support of Research of Bahia - FAPESB. Thank you to Juliet O. Santana for producing the map.

Author's contribution DCCS, VFES and TCP commanded fieldwork insite, CGZ and RSA performed the animal processing, CGZ, HK and TCP performed the analysis, CGZ, HK, TCP, FC and MB wrote the manuscript, FC, HK and MB provided overall advisorship, developed the sampling design.

Funding This study was funded by a grant awarded by the Medical Research Council (MRC) of the United Kingdom (award MR/P024084/ 1) and FAPESB (10206/2015). Open access funding provided by Swedish University of Agricultural Sciences.

Data availability The data used in this study is stored in a RedCap database at Instituto Gonçalo Moniz - FIOCRUZ/BA, currently accessible for personnel only.

\section{Compliance with ethical standards}

Conflict of interest The authors state no conflicts of interest.

Code availability Not applicable.

Ethics approval This study was approved by the Ethics Committee on Research of Fundação Oswaldo Cruz, under protocol 019/2016. 
Open Access This article is licensed under a Creative Commons Attribution 4.0 International License, which permits use, sharing, adaptation, distribution and reproduction in any medium or format, as long as you give appropriate credit to the original author(s) and the source, provide a link to the Creative Commons licence, and indicate if changes were made. The images or other third party material in this article are included in the article's Creative Commons licence, unless indicated otherwise in a credit line to the material. If material is not included in the article's Creative Commons licence and your intended use is not permitted by statutory regulation or exceeds the permitted use, you will need to obtain permission directly from the copyright holder. To view a copy of this licence, visit http://creativecommons.org/licenses/by/4.0/.

\section{References}

Barton K (2018) MuMIn: Multi-Model Inference, 1.42.1 edn.

Bates D, Maechler M, Bolker B, Walker S (2015) Fitting linear mixedeffects models using lme4 journal of statistical software 67:1-48 doi: https://doi.org/10.18637/jss.v067.i01

Blanchard DC, Fukunaga-Stinson C, Takahashi LK, Flanelly KJ, Blanchard RJ (1984) Dominance and aggression in social groups of male and female rats. Behavioral Processes 9:31-48

Burnham KP, Anderson DR (2002) Model selection and multimodel inference: a practical information-theoretic approach. Springer, New York doi:https://doi.org/10.1007/b97636

Byers KA, Lee MJ, Bidulka JJ, Patrick DM, Himsworth CG (2019a) Rat in a Cage: Trappability of Urban Norway Rats (Rattus norvegicus) Frontiers in Ecology and Evolution 7 doi:https://doi.org/10.3389/ fevo. 2019.00068

Byers KA, Lee MJ, Donovan CM, Patrick DM, Himsworth CG (2017) A novel method for affixing Global Positioning System (GPS) tags to urban Norway rats (Rattus norvegicus): feasibility, health impacts and potential for tracking movement Journal of Urban Ecology 3: jux010

Byers KA, Lee MJ, Patrick DM, Himsworth CG (2019b) Rats About Town: A Systematic Review of Rat Movement in Urban Ecosystems. Frontiers in Ecology and The Environment 7:1-12

Cavia RC, GR., Suárez OV (2009) Changes in rodent communities according to the landscape structure in an urban ecosystem. Landscape and Urban Planning 90:11-19

Clapperton BK (2006) A review of the current knowledge of rodent behaviour in relation to control devices vol 263. Science for Conservation. Science \& Technical Publishing, Wellington

Colvin BA, Degregorio R, Fleetwood C (1996) Norway Rat Infestation of Urban Landscaping and Preventative Design Criteria Proceedings of the Seventeenth Vertebrate Pest Conference 9

Combs M et al. (2018) Urban rat races: spatial population genomics of brown rats (Rattus norvegicus) compared across multiple cities proceedings of the Royal Society B: biological sciences 285:1-10

Costa $\mathrm{F}$ et al. (2014a) Infections by Leptospira interrogans, Seoul virus, and Bartonella spp. among Norway rats (Rattus norvegicus) from the urban slum environment in Brazil vector-borne and zoonotic diseases 14:33-40 doi:https://doi.org/10.1089/vbz.2013.1378

Costa F, Ribeiro GS, Felzemburgh RDM, Santos N, Reis RB, Santos AC, Fraga DBM, Araujo WN, Santana C, Childs JE, Reis MG, Ko AI (2014b) Influence of household rat infestation on leptospira transmission in the urban slum environment PLoS neglected tropical diseases 8:e3338 doi:https://doi.org/10.1371/journal.pntd.0003338

Costa $\mathrm{F}$ et al. (2015) Patterns in Leptospira shedding in Norway rats (Rattus norvegicus) from Brazilian slum communities at high risk of disease transmission PLoS neglected tropical diseases 9: e0003819 doi:https://doi.org/10.1371/journal.pntd.0003819

Davis DE, Fales WT (1950) The rat population of Baltimore, 1949. Am J Hyg 52:143-146
Davis DE, Hall O (1951) The seasonal reproductive condition of female Norway (Brown) rats in Baltimore. Maryland Physiological Zoology 24:9-20

Desvars-Larrive A, Baldi M, Walter T, Zink R, Walzer C (2018) Brown rats (Rattus norvegicus) in urban ecosystems: are the constraints related to fieldwork a limit to their study? Urban Ecosyst 21:951964. https://doi.org/10.1007/s11252-018-0772-8

Desvars-Larrive A, Pascal M, Gasqui P, Cosson JF, Benoît E, Lattard V, Crespin L, Lorvelec O, Pisanu B, Teynié A, Vayssier-Taussat M, Bonnet S, Marianneau P, Lacôte S, Bourhy P, Berny P, Pavio N, le Poder S, Gilot-Fromont E, Jourdain E, Hammed A, Fourel I, Chikh F, Vourc'h G (2017) Population genetics, community of parasites, and resistance to rodenticides in an urban brown rat (Rattus norvegicus) population. PLoS One 12:e0184015

Dexter N (2003) Stochastic models of foot and mouth disease in feral pigs in the Australian semi-arid rangelands Journal of Applied Ecology 40

Edwards GP, Pople AR, Saalfeld K, Caley P (2004) Introduced mammals in Australian rangelands: Future threats and the role of monitoring programmes in management strategies. Austral Ecology 29:40-50

Felzemburgh RD et al. (2014) Prospective study of leptospirosis transmission in an urban slum community: role of poor environment in repeated exposures to the Leptospira agent PLoS neglected tropical diseases 8:e2927 doi:https://doi.org/10.1371/journal.pntd.0002927

Feng AY, Himsworth CG (2014) The secret life of the city rat: a review of the ecology of urban Norway and black rats (Rattus norvegicus and Rattus rattus). Urban Ecosystems 17:149-162

Garchitorena A, Sokolow SH, Roche B, Ngonghala CN, Jocque M, Lund A, Barry M, Mordecai EA, Daily GC, Jones JH, Andrews JR, Bendavid E, Luby SP, LaBeaud AD, Seetah K, Guégan JF, Bonds MH, de Leo GA (2017) Disease ecology, health and the environment: a framework to account for ecological and socio-economic drivers in the control of neglected tropical diseases Philosophical Transactions of the Royal Society of London B Biological Sciences 372 doi:https://doi.org/10.1098/rstb.2016.0128

Gioverdani M, Consiglio AR, Barros HMT, Lucion AB (2000) Pup age and aggressive behavior in lactating rats. Brazilian Journal of Medical and Biological Research 33:1083-1088

Glass GE, Childs JE, Korch GW, LeDuc JW (1989) Comparative ecology and social interactions or Norway rat (Rattus norvegicus) populations in Baltimore, Maryland Occasional Papers of the Museum of Natural History of the University of Kansas:1-33

Gurtler RE et al. (2008) Impact of Environment and Social Gradient on Leptospira Infection in Urban Slums PLoS neglected tropical diseases 2:e228 doi:https://doi.org/10.1371/journal.pntd.0000228

Hampton JO et al (2004) Molecular techniques, wildlife management and the importance of genetic population structure and dispersal: a case study with feral pigs. Journal of Applied Ecology 41:735-743. https://doi.org/10.1111/j.0021-8901.2004.00936.x

Himsworth CG, Bai Y, Kosoy MY, Wood H, DiBernardo A, Lindsay R, Bidulka J, Tang P, Jardine C, Patrick D (2015) An investigation of Bartonella spp., rickettsia typhi, and Seoul hantavirus in rats (Rattus spp.) from an Inner-City Neighborhood of Vancouver, Canada: is pathogen presence a reflection of global and local rat population structure? Vector Borne Zoonotic Diseases 15:21-26

Himsworth CG, Bidulka J, Parsons KL, Feng AYT, Tang P, Jardine CM, Kerr T, Mak S, Robinson J, Patrick DM (2013) Ecology of Leptospira interrogans in Norway rats (Rattus norvegicus) in an inner-city neighborhood of Vancouver. Canada PLoS neglected tropical diseases 7:e2270. https://doi.org/10.1371/journal.pntd. 0002270

Himsworth CG, Jardine CM, Parsons KL, Feng AY, Patrick DM (2014) The characteristics of wild rat (Rattus spp.) populations from an inner-city neighborhood with a focus on factors critical to the understanding of rat-associated zoonoses. PloS one 9:e91654. https:// doi.org/10.1371/journal.pone.0091654 
Innes J (2001) Advances in New Zealand mammalogy 1990-2000: European rats. J R Soc N Z 31:111-125

Lambert M, Vial F, Pietravalle S, Cowan D (2017) Results of a 15-year systematic survey of commensal rodents in English dwellings nature scientific reports $7: 15882$

Lutermann $\mathrm{H}$ et al (2017) Population genetics, community of parasites, and resistance to rodenticides in an urban brown rat (Rattus norvegicus) population. PloS one 12:e0184015. https://doi.org/10. 1371/journal.pone.0184015

Macdonald DW, Mathews F, Berdoy M (1999) The behaviour and ecology of Rattus norvegicus: from opportunism to kamikaze tendencies. In: Singleton GH, Leirs H (eds) Ecologically based rodent management. ACIAR monographs, vol 59. Brown Prior Anderson, Melbourne, pp. 49-80

Masi E, Pino FA (2011) Niche overlap and resource partition among three urban rodent species. In: Triunveri A, Scalise D (eds) Rodents: Habitat, Pathology and Environmental Impact. Nova Publishers, pp. $77-98$

Masi E, Vilaça PJ, Razzolini MTP (2009) Evaluation on the effectiveness of actions for controlling infestation by rodents in campo Limpo region, São Paulo Municipality. Brazil International Journal of Environmental Health Research 19:291-304

McKinney ML (2002) Urbanization, Biodiversity and Conservation. BioScience 52:883-890

Meaney MJ, Stewart J (1979) Environmental factors influencing the affiliative behavior ofmale and female rats (Rattus norvegicus). Animal Learning and Behavior 7:397-405

Minter A, Diggle PJ, Costa F, Childs J, Ko AI, Begon M (2017) Evidence of multiple intraspecific transmission routes for Leptospira acquisition in Norway rats (Rattus norvegicus). Epidemiology and Infection 145:3438-3448. https://doi.org/10.1017/ S0950268817002539

Minter A, Diggle PJ, Costa F, Childs J, Ko AI, Begon M (2018) A model for leptospire dynamics and control in the Norway rat (Rattus norvegicus) the reservoir host in urban slum environments. Epidemics 25:26-34. https://doi.org/10.1016/j.epidem.2018.05.002

Morand S et al (2015) Global parasite and Rattus rodent invasions: the consequences for rodent-borne diseases. Integrative Zoology 10: 409-423. https://doi.org/10.1111/1749-4877.12143

Orgain H, Schein MW (1953) A Preliminary Analysis of the Physical Environment of the Norway Rat. Ecology 34:467-473

Panti-May JA et al (2016) A two-year ecological study of Norway rats (Rattus norvegicus) in a Brazilian urban slum. PloS one 11: e0152511. https://doi.org/10.1371/journal.pone.0152511
Parsons MH, Banks PB, Deutsch MA, Corrigan RF, Munshi-South J (2017) Trends in urban rat ecology: a framework to define the prevailing knowledge gaps and incentives for academia, pest management professionals (PMPs) and public health agencies to participate journal of urban ecology 3 doi:https://doi.org/10.1093/jue/jux005

Peig J, Green AJ (2009) New perspectives for estimating body condition from mass/length data: the scaled mass index as an alternative method. 118:1883-Oikos, 1891. https://doi.org/10.1111/j.1600-0706. 2009.17643.x

Porter FH et al (2015) Morphometric and demographic differences between tropical and temperate Norway rats (Rattus norvegicus). Journal of Mammalogy 96:317-323. https://doi.org/10.1093/ jmammal/gyv033

Puckett EE et al (2016) Global population divergence and admixture of the brown rat (Rattus norvegicus). Proceedings of the Royal Society B: biological sciences 283:20161762. https://doi.org/10.1098/rspb. 2016.1762

R Core Team (2018) R: a language and environment for statistical computing. R Foundation for Statistical Computing, Vienna

Robertson BC, Gemmell NJ (2004) Defining eradication units to control invasive pests. Journal of Applied Ecology 41:1042-1048

Santos NdJ, Sousa E, Reis MG, Ko AI, Costa F (2017) Rat infestation associated with environmental deficiencies in an urban slum community with high risk of leptospirosis transmission Cadernos de Saúde Pública 33 doi:https://doi.org/10.1590/0102-311x00132115

Stojčević D, Marinculić A, Mihaljević Ž (2002) Prevalence of Capillaria hepatica in Norway rats (Rattus norvegicus) in Croatia VETERINARSKI ARHIV 72:141-149

Traweger D, Travnitzky R, Moser C, Walzer C, Bernatzky G (2006) Habitat preferences and distribution of the brown rat (Rattus norvegicus Berk.) in the city of Salzburg (Austria): implications for an urban rat management. J Pest Sci 79:113-125

Villafañe IEG, Cavia R, Victoria Vadell M, Suárez OV, Busch M (2013) Differences in population parameters of Rattus norvegicus in urban and rural habitats of central Argentina Mammalia 77 doi:https://doi. org/10.1515/mammalia-2012-0075

Wickham H (2017) Tidyverse: easily install and load the 'Tidyverse', 1.2.1 edn.,

Zenger KR, Eldridge MD, Cooper DW (2003) Intraspecific variation, sex-biased dispersal and phylogeography of the eastern grey kangaroo (Macropus giganteus) heredity 91:153-162 doi:https://doi.org/ 10.1038/sj.hdy.6800293 